\title{
As múltiplas transformações em Pessach: a travessia de Carlos Heitor Cony ${ }^{1}$
}

\author{
Multiple transformations in Pessach: a travessia by Carlos Heitor Cony
}

Zuzana Burianová

\begin{abstract}
Resumo: O objetivo do artigo é explorar a transformação pessoal experimentada pelo protagonista-narrador do romance Pessach: $a$ travessia, do escritor brasileiro Carlos Heitor Cony, cujo enredo decorre nos primeiros anos após o golpe militar de 1964. A análise parte da compreensão dessa obra como um romance de formação (Bildungsroman) e da sua inserção no quinto tipo deste gênero romanesco, distinguido por Bakhtin, que se caracteriza pela interligação da formação do protagonista com a evolução histórica. Logo a seguir, observamos três tipos de transformação pelos quais passa o protagonista do romance - rumo ao seu engajamento sócio-político, ao compromisso artístico e à busca das raízes judaicas -, que são analisados em estreita relação com o momento histórico pelo qual passava o País. Palavras-chave: Ditadura militar. Romance de formação. Engajamento sociopolítico. Judaísmo.

Abstract: The purpose of this article is to explore the personal transformation experienced by the protagonist-narrator of the novel Pesach: a travessia by the Brazilian writer Carlos Heitor Cony, whose plot takes place in the first years after the military coup of 1964 . The analysis is based on the understanding of this book as a novel of formation (Bildungsroman) and on its insertion in the fifth type of this genre distinguished by Bakhtin, characterized by the connection of the protagonist's formation with the historical developments. We observe three types of transformation of the protagonist in the Cony's novel - towards his sociopolitical engagement, artistic commitment and pursuit of Jewish roots - and we analyze them in close relation with the historical moment Brazil was going through. Keywords: Military dictatorship. Novel of formation. Sociopolitical engagement. Judaism.
\end{abstract}

\section{Introdução}

Digo: o real não está na saída nem na chegada: ele se dispõe para a gente é no meio da travessia (ROSA, 1994, p. 86).

Pessach: a travessia (1967), oitavo romance do escritor e jornalista brasileiro Carlos Heitor Cony (1926-2018), encontra-se entre os livros mais significativos que, publicados nos primeiros anos após o golpe militar, abordam diretamente o tema da resistência ao novo regime. A obra surge no período em que a "ditadura envergonhada" (GASPARI, 2014) ainda não censurava radicalmente as produções culturais, tentando criar a impressão da con- tinuação da legitimidade. Até decretar o AI-5, em 1968, o regime praticava uma "política de contenção" (NETTO, 2014, p. 117), ou seja, tolerava, até certo ponto, a circulação da produção cultural, desde que esta se restringisse a círculos intelectuais e não se propagasse por meios operários e camponeses. Neste clima surgiram romances de cunho político que criticavam abertamente o regime e promoviam uma oposição armada; além de Pessach: a travessia, podemos mencionar $O$ senhor embaixador, de Erico Verissimo (1965), ou Quarup (1967), de Antonio Callado. Como explica Zuenir Ventura:

1 Este artigo foi escrito no âmbito do apoio do Ministério da Educação da República Checa à Universidade Palacký em Olomouc (IGA_FF_2018_015).

2 Universidade Palacký em Olomouc (UP) - República Checa. ORCID: Orcid: http://orcid.org/oooo-ooo2-3530-8473. E-mail: zuzana. burianova@upol.cz 
[...] a conjuntura política ajudava a ascender a imaginação revolucionária: o desgaste do governo militar era crescente, não aparecera ainda 'o milagre brasileiro', era a recessão, e uma grande descrença tomava conta da juventude em relação aos partidos políticos legais, o MDB e a Arena, chamados na época de partidos do sim e do sim, senhor (VENTURA, 2013, p. 66-67).

Depois de 1964, a "politização dos intelectuais" (NETTO, 2014, p. 115), observada já desde o início da década de 1960, intensificou-se ainda mais em uma atmosfera de crescentes lutas pela democratização da sociedade brasileira e do frequente debate, na esquerda intelectual, acerca da importância do engajamento da arte e do papel da cultura popular. Em palavras de José Paulo Netto, "é paradoxal o panorama que o Brasil oferece entre 1964 e 1968: sob uma ditadura reacionária, floresce uma cultura predominantemente de esquerda" (NETTO, 2014, p. 117, grifo do autor). O ano da publicação do romance de Cony é marcado por uma intensa produção em vários campos artísticos: no cinema (Terra em transe, de Glauber Rocha), no teatro (as estreias de Navalha na carne, de Plínio Marcos, e de O rei da vela, de Oswald de Andrade), nas artes plásticas (as obras de Hélio Oiticica ou Lygia Pape), na música (a Tropicália) etc.

Carlos Heitor Cony não se filiou a nenhum partido político e também criticava o governo Goulart, por considerar as suas estratégias demagógicas e populistas. No entanto, logo após a eclosão do golpe militar, que ele mais tarde chamou de "a revolução dos caranguejos" (CONY, 2004), pela sua tendência retrógrada, foi um dos primeiros a pronunciar-se abertamente, como cronista no jornal Correio da Manhã, contra a sua legalidade. O lançamento do seu livro de crônicas que evocam o golpe, $O$ ato e o fato, em julho de 1964, tornou-se, "um ato de resistência" e o livro, cuja primeira edição se esgotou rapidamente, teve uma grande repercussão (REIMÃO, 2011, p. 20). Quando, no ano seguinte, foi publicada uma crônica sua, criticando o AI-2, e o Correio da Manhã foi, em reação à mesma, ameaçado de ser encerrado pelo governo, Cony demitiu-se do jornal. Durante o regime passou por várias prisões e interrogatórios policiais.

Apesar de Pesach: a travessia não ser o romance mais lido do autor ${ }^{3}$, e de alguns críticos terem chamado a atenção para alguns aspectos problemáticos do ponto de vista linguístico, estrutural e temático ${ }^{4}$, trata-se de uma obra importante, que reflete as principais questões e preocupações da esquerda brasileira após 1964. Semelhantemente a Quarup, também o romance de Cony capta o processo de amadurecimento e a gradual transformação do protagonista rumo ao engajamento social e político, que acaba pela sua decisão de entrar na luta armada. Nos dois romances, embora difiram radicalmente no espaço do tempo histórico abrangido, encontramos vários traços do Bildungsroman, ou seja, do romance de formação. Baseando-nos na tipologia bakhtiniana, podemos inserir as duas obras no quinto tipo deste gênero romanesco, que Bakhtin caracteriza como "realista", porque "a evolução do homem é indissolúvel da evolução histórica”, ou seja, a formação (transformação) do homem realiza-se no "tempo histórico real". Neste tipo de romance, "a imagem do homem em devir perde seu caráter privado (até certo ponto, claro) e desemboca numa esfera totalmente diferente, na esfera espaçosa da existência histórica" (BAKHTIN, 1997, p. 240). O nosso objetivo neste trabalho será abordar a transformação pessoal, pela qual passa o protagonista do romance Pessach: a travessia, colocando-a em estreita relação com o tempo histórico de que fala Bakhtin. Concretamente, vamos analisar três tipos de transformação, que distinguimos na trajetória do protagonista, inserindo-os no contexto do debate, vigente na esquerda brasileira após 1964, acerca das possíveis

\footnotetext{
3 O romance que atingiu uma grande repercussão foi, por exemplo, Quase memória (1995), inspirado pelas lembranças do pai do escritor, o jornalista Ernesto Cony Filho.

4 Renato Franco, por exemplo, encontra no livro vários “pontos de desequilíbrio", como "a visão maniquísta” na adesão ao ideal revolucionário da parte do protagonista, um certo desleixo da linguagem, ou o "sutil deslocamento de gêneros" entre as duas partes do livro - uma de carácter dramático, outra de épico (FRANCO 1998, p. 64-64).
} 
vias da transformação do País e acerca do papel do intelectual neste processo.

O enredo do romance, narrado em primeira pessoa, ocorre nos primeiros anos do regime militar, sendo o seu protagonista-narrador Paulo Simões, escritor carioca de proveniência judaica. A sua personalidade, o estilo de vida e as relações com os outros são apresentados na primeira parte, intitulada "Pessach (A passagem por cima)", que capta o dia do seu quadragésimo aniversário. Nesse dia Paulo realiza uma série de encontros: em casa recebe a sua amante e depois o ex-colega Sílvio, acompanhado por uma mulher de nome Vera; visita a filha no internato; passa por casa da sua ex-mulher; vai almoçar em casa dos pais; encontra-se no escritório com o seu editor. No entanto, aquilo que no início parecia ser um dia de aniversário comum, torna-se um dia perturbador, de acontecimentos inesperados.

Na segunda parte, que leva o título "A travessia", são narrados os acontecimentos iniciados no dia seguinte, quando Paulo pretende sair da cidade, por algum tempo, para se dedicar à escrita, mas é forçado por Vera a levar um revolucionário ferido para uma antiga fazenda de café que serve de campo de treino de guerrilheiros. Por razões de segurança, Paulo tem que ficar lá. Apesar do seu inicial ressentimento, vai se envolvendo cada vez mais com a vida e as pessoas na fazenda. Os acontecimentos políticos do país obrigam a liderança a abandonar o campo e a deslocar-se para o sul do país, para apoiar outro grupo guerrilheiro que planeja iniciar a ofensiva. Paulo decide ficar com eles. O plano é, porém, traído e os guerrilheiros são dizimados pelo exército. $\mathrm{O}$ único a sobreviver, atravessando a fronteira com o Uruguai, é Paulo.

É evidente que o dia do aniversário do protagonista-narrador se tenha tornado um divisor de águas que separa a sua vida em duas metades. Esse dia guarda não apenas a simbologia do nascimento - intensificada pelo motivo naturalista do esboço do útero da sua mãe, que Paulo obtém do médico familiar a fim de lhe explicar o problema de saúde dela -, mas também da morte, através da cápsula de cianureto, para ser usada no caso de perigo, que ele recebe do pai, aterrorizado pela ideia de possível perseguição de judeus no novo regime. A morte aparece também na forma do suicídio de um homem, que se atira da janela do prédio em que Paulo mora. Olhando para a cara do morto de perto, Paulo, nesse "rosto bastante íntimo, embora desagradável" (CONY, 1967, p. 117) reconhece o seu próprio rosto. Este motivo, de teor fantástico, pode ser interpretado de várias maneiras: pode aludir à atual existência vazia de Paulo, indicar o fim de uma época da sua vida, ou pressagiar o perigo do caminho pelo qual ele vai enveredar. Assim, a transformação da sua personalidade, inicia-se no dia do seu aniversário, devido tanto a circunstâncias de ordem externa, sobretudo ao encontro com Sílvio e Vera, quanto a motivos internos, representados por um anseio, que se concretiza na decisão de terminar um antigo projeto literário - um romance dedicado ao tema do êxodo dos judeus. Podemos observar que a transformação ocorre, de fato, em três campos: no sócio-político, no artístico e no religioso.

\section{A travessia sócio-política}

No início do romance, Paulo Simões é apresentado como um escritor profissional que leva uma vida solitária, materialmente abastada, dividida entre trabalho, visitas ocasionais aos pais e à filha adolescente, e encontros com a sua amante, mulher casada. Tudo isso sem grandes compromissos, entusiasmo ou ideais de qualquer tipo. O que ele preza mais parece ser a sua liberdade pessoal, como demonstram as suas próprias palavras: "Tudo corre bem. Não tenho amigos nem dívidas - duas coisas que incomodam" (CONY, 1967, p. 3). Também não se interessa por questões sociais e políticas, e nem se incomoda quando as pessoas ao seu redor apontam para a sua alienação. Um traço simpático nele é a sua sinceridade: ele não esconde o seu comodismo e admite, abertamente, ser "um homem que até agora se gastou num individualismo estéril e confortável" (CONY, 1967, p. 87). No diálogo com Sílvio, ele diz acerca do seu apoliticismo o seguinte: 
- Não gosto do governo atual, mas jamais gostei de governo algum. Politicamente, sou anarquista comodista, e, por isso, inofensivo e covarde. Não estou disposto a dar ou a receber tiro por causa da liberdade, da democracia, do socialismo, do nacionalismo, do povo, das criancinhas do nordeste que morrem de fome. $\mathrm{O}$ fato político não me preocupa, é tudo.

- Mas você tem assinado manifestos!

- Isso é fácil. Assino-os aqui mesmo, no meu gabinete, de short, as pernas de fora, o ar refrigerado, o cachimbo [...]. Não me custa passar por bom moço.

- Mas Paulo, isso é loucura!

- Que loucura?

- Você não pode se desprezar a esse ponto!

- Pois me deprezo... (CONY, 1967, p. 3).

Na postura proclamadamente cínica do narrador podemos sentir não apenas a descrença em relação a ideologias e projetos políticos, mas também certa hesitação ou impasse perante a complexidade da situação pela qual o País passava. Segundo Renato Franco, tal indecisão refletia a atmosfera do período: "é uma marca da época e talvez ateste a real dificuldade dos escritores em se posicionar tanto ante as transformações do país - as quais frequentemente não entendiam - quanto a ditadura militar" (FRANCO, 1998, p. 58). O crítico acrescenta que esta vacilação, em relação às questões do engajamento dos intelectuais e do modo de resistência contra o regime, se intensificaram ainda mais depois da proclamação do AI-5, quando foi instaurada uma rígida censura e se tornava cada vez mais evidente o fracasso da luta armada no Brasil ${ }^{5}$.

Contudo, a sinceridade e a capacidade de autocrítica de Paulo Simões demonstram que nele ocorre um processo de questionamento em relação ao rumo da sua vida, como homem e artista. Ao seu potencial de mudança aludem, logo no início, as esperanças de Sílvio, que acredita na sua adesão à guerrilha, assim como o seu próprio projeto de criar uma obra relevante, diferente das que escrevera até à altura. A transforma- ção da sua atitude ideológica ocorre, gradualmente, na segunda parte do romance. Trata-se de uma metamorfose lenta, acompanhada de sensações de renitência, dúvidas e ceticismo que, porém, culmina no quase patético fim do livro em que o protagonista consegue atravessar a fronteira e, agarrando uma metralhadora, caminha, "obstinado e lúcido, a serviço do homem, de encontro à vida” (CONY, 1967, p. 301).

Há uma série de fatores que contribuem para a mudança ideológica de Paulo Simões. A principal influência é desempenhada pelo seu contato direto com as pessoas politicamente engajadas. Durante a sua estada no campo de guerrilha, ele fica impressionado com a vida disciplinada e organizada do lugar e pela determinação dos militantes. O autor apresenta personagens fortes, embora contraditórias como, por exemplo, Macedo, um carismático e ao mesmo tempo trágico líder guerrilheiro negro, pelo qual Paulo sente uma mistura de admiração e repugnância. Além da influência desta figura na transformação do protagonista, a luta contra a opressão no romance anda de mãos dadas com a paixão amorosa; isto é, aliás, um traço comum de várias obras que tematizam a resistência contra o regime, como documentam, por exemplo, os romances políticos de Antonio Callado (Quarup, Bar Dom Juan, Reflexos do baile, Sempreviva). Paulo Simões parece aderir à guerrilha também por causa do envolvimento amoroso com Vera, contra o qual no início luta, a nível racional, por não estar acostumado a este tipo de sentimento: "Nunca amei suficientemente a ninguém. Há minha filha, mas isso é diferente, é coisa da carne, do instinto. Mas nunca amei na vida" (CONY, 1967, p. 201). Podemos acrescentar que a relação com Vera não está livre de laivos do amor romântico, como demonstra o motivo da transformação motivada pelo amor ou o do sacrifício pelo amor (no final do romance Vera morre salvando a vida de Paulo em um tiroteio).

Outro fator importante na mudança do protagonista é o deslocamento no espaço, ou seja, a sua saída daquilo que poderíamos chamar, inspirados por Bakhtin, do cronotopo da casa e do lar, que no

\footnotetext{
5 Cf. FRANCO, 1998, p. 58.
} 
romance de Cony adquire significados de estagnação e egocentrismo, e a sua entrada no cronotopo da natureza (BAKHTIN, 1993, p. 211-362). Novamente podemos traçar paralelos com Quarup, em que aos espaços do mosteiro, como símbolo de proteção e isolamento, e depois da cidade, que aparece associada à superficialidade e à acomodação, se opõem os cenários rurais, da mata do Centro-Oeste e do campo nordestino, nos quais ocorre o amadurecimento do protagonista. Renato Franco destaca o ambiente da fazenda, onde Paulo Simões convive com os militantes, como um motivo relevante na sua consciencialização política, chamando a atenção para "uma espécie de idealização da eventual identificação entre o revolucionário e o homem 'selvagem', vale dizer, 'simples'” (FRANCO, 1998, p. 63).

Ao lado do espaço da natureza, a transformação do protagonista-narrador no romance de Cony é associada também ao tema da viagem, ou seja, ocorre dentro do que Bakhtin chama do cronotopo da estrada e que considera como fulcral na literatura mundial: "rara é a obra que passa sem certas variantes do motivo da estrada, e muitas obras estão francamente construídas sobre o cronotopo da estrada, dos encontros e das aventuras que correm pelo caminho" (BAKHTIN, 1993, p. 223). A travessia interior de Paulo é acompanhada por vários deslocamentos geográficos: da cidade do Rio para a serra, do Rio para a capital gaúcha, de lá para a mata e, finalmente, para a fronteira uruguaia, onde se completa não apenas a viagem de Paulo, mas também os destinos dos seus dois principais companheiros, Vera e Macedo. Enquanto "o mestre" e "a mensageira" do projeto revolucionário morrem, cumprindo o seu papel na iniciação do protagonista, ele próprio continua a missão.

Embora a radical mudança da mundividência do protagonista possa aparecer um tanto inverossímil, devido à força da sua descrença e ao cinismo inicial, ela apresenta-se como menos gratuita se tomarmos em consideração a sua já mencionada angústia em relação à própria existência e à criação literária. Além disso, o livro parece retratar de um modo bastante realista o dilema do artista na época. Este tinha, de fato, três opções de como se engajar na luta contra o regime: através da sua obra artística; participando na luta política, tal como propunha, por exemplo, o Partido Comunista; ou entrando na luta armada como propagavam as organizações de guerrilha. A desilusão com o debate político e a crescente radicalização da esquerda brasileira, depois da derrota das tendências democráticas em 1964, levou muitos a optarem justamente pela terceira via, como explica Zuenir Ventura:

\begin{abstract}
Essa geração, como lembraria Vladimir [Palmeira], tinha tirado de 64 uma lição: 'não se pode confiar na legalidade burguesa. Perdemos em 64 porque os trabalhadores não reagiram'. Raciocinando assim, eles achavam que as transformações sociais só viriam, de fato, pela luta armada (VENTURA, 2013, p. 65).
\end{abstract}

\section{A travessia artística}

A mudança da postura ideólogica do narrador-protagonista vem estreitamente acompanhada pela sua transformação no campo da criação literária. Até aos seus quarenta anos, com a mesma visão cética e pessimista com a qual se aproximava do mundo e se encarava a si próprio, Paulo escrevia livros para o público burguês: apolíticos, sarcásticos, existencialistas. Escrevia por encomenda, sendo o seu principal objetivo o ganho financeiro, que lhe garantia uma existência materialmente independente. A respeito da sua obra literária, Paulo não parece alimentar muita ilusão, mas mostra-se indiferente às críticas negativas. Sem negar o apoliticismo dela, chama, porém, a atenção para o fato de os seus livros criticarem a vida burguesa e as relações dentro da família:

Denuncio em todos os meus livros uma coisa que até agora tem sido pouco denunciada: a família. A religião, a sociedade, os governos, as ditaduras, o capitalismo, o imperialismo, todos os males da época - da nossa e das demais épocas - foram e estão sendo denunciados constantemente. Eu denuncio a célula de todos esses males. A família cristã-ocidental de hoje, em sua estrutura social e econômica, é ainda a mesma de todos os tempos primitivos (CONY, 1967, p. 253). 
Fica também evidente que a opção de escrever uma literatura comercial não parte apenas do pragmatismo pessoal, mas também da demanda do próprio mercado, como documenta, por exemplo, o pedido do editor para Paulo escrever "um ensaio picaresco sobre a virgindade da mulher" (CONY, 1967, p. 90), o qual inspira Paulo a criar um conto sobre um bidê. A frivolidade do tema dessa encomenda alude à comercialização da produção artística, cada vez mais dependente das exigências do mercado cultural, que se aprofunda na sociedade brasileira nos finais da década 1960 e na década seguinte. Por outro lado, nos anos após o golpe, os temas sociais e políticos ganharam visibilidade na produção artística, ainda não atingida drasticamente pela censura. Isso reflete-se, por exemplo, no fato de o mesmo editor recriminar Paulo, não sem certa hipocrisia, pela sua postura apolítica: "O pessoal por aqui anda irritado com você, seus livros são alienados, você não se compromete, não se engaja, muita gente me torce o nariz porque edito seus livros" (CONY, 1967, p. 92).

No dia do seu aniversário, Paulo ouve a crítica, de que a sua obra é alienada e banal, também de outras pessoas. O primeiro a proferi-la é Sílvio, que aponta para o seu estilo de vida estéril e cômodo e para a temática vazia dos seus livros:

- Acho você, como escritor, irrecuperável. O diabo é que a sua literatura faz algum sucesso, você vive bem, tem leitores, tem amantes, enfim, um escritor ao gosto do século passado, personagem mais ou menos de opereta, como um duque, um pintor de Montparnasse, um poeta de Sardou ou de Murger. [...] Olha só: vocês vivem fuçando num poço estéril: o vácuo do homem, a problemática do homem...

- É uma escola - defendo por conta própria a classe. - Você sabe que só o homem problemático pode ser objeto de uma pesquisa, de uma obra de arte.

- Mas por que não descem vocês ao fundo do problema? Em vez de aceitarem o homem problemático, procurem, se não solucionar, ao menos conhecer o problema do homem (CONY, 1967, p. 20).
Horas a seguir, Paulo ouve algo parecido da sua filha de dezesseis anos, que se interessa, no internato, pela leitura de literatura engajada e quer estudar sociologia: "Tem uma garota aqui que o pai está exilado no Chile. Ela recebe literatura subversiva, já li muita coisa. Papai, eu acho você um bocado alienado!" (CONY, 1967, p. 45).

Contudo, apesar da sua criação por encomenda, Paulo Simões já há algum tempo nutre o desejo de escrever um romance sobre um tema relevante, sem saber, porém, defini-lo. Como aponta Renato Franco, tal motivo traduz "o prestígio que o romance ainda gozava entre os vários meios expressivos então disponíveis; prestígios e importância que, porém, rapidamente desapareceriam" (FRANCO, 1998, p. 58). Um dos temas sobre os quais Paulo pensa é relacionado com o judaísmo. O seu pai é um judeu alemão que fugiu da Alemanha nazi para o Brasil onde mudou o sobrenome de Simon para Simões. Toda a vida tentou esconder a sua origem, atemorizado pela ideia da volta do Holocausto. Após a instauração do regime militar, o seu pavor do antissemitismo intensifica-se até ao ponto de o levar, junto com a sua esposa, ao suicídio. Paulo, por sua vez, sem ter sido educado na tradição judaica e negando qualquer laço afetivo para com as suas raízes, sente, porém, um interesse latente pela problemática judaica. No dia do seu aniversário, recebe da sua ex-esposa um esboço do livro que há tempo começou a escrever, sobre o êxodo do povo hebraico - "a geração que preferiu a fome e a morte no deserto a continuar escrava" (CONY, 1967, p. 45). Isso leva-o à decisão de, inspirado na história do seu pai e, simultaneamente, de si próprio, continuar o projeto, criando a história de um judeu que enfrenta o problema do retorno às suas raízes.

Durante a sua permanência no campo de treino de guerrilheiros, Paulo pretende escrever o conto encomendado sobre o bidê, porém o ambiente do campo priva-o da capacidade de concentrar-se em um tema tão banal, quase amoral. Tenta, pelo menos, dedicar-se ao romance sobre o judaísmo, sendo esta tentativa também frustrada pela falta de motivação. Escrever literatura parece, face às pessoas mutiladas pelas forças de repressão, que ele encontra na fazenda, uma 
atividade inútil e até certo ponto alibista. Além disso, também aqui ele ouve várias críticas em relação ao seu egocentrismo, por exemplo, da médica do campo:

Você só pensa em si. Há um mundo à sua volta, passando fome, sem liberdade, torturado pela polícia, e você só pensa em suas angústias, em seus probleminhas pessoais. Compreendo que precisa de tudo isso para fazer seus livros, mas a vida é mais importante que qualquer livro (CONY, 1967, p. 208).

Sob a influência do contato quotidiano com os guerrilheiros, conhecendo mais de perto as suas vidas e os motivos pelos quais se juntaram à organização militante, Paulo passa por uma radical transformação ética que o leva à decisão de deixar, por enquanto, a literatura de lado e agir:

Há em mim uma comportada rebeldia contra tudo o que é mundo. Essa rebeldia limitou-se, até agora, a uma obra fracionária, mais ou menos moralista e mais ou menos escandalosa. O certo é que não vou escrever nem a encomenda da editora, nem o romance que me prometo há anos. Os tempos são de ação: estou agindo (CONY, 1967, p. 219).

Essa rebeldia, orientada até à altura para a crítica da família burguesa na sua escrita, une o protagonista, de fato, com a geração mais jovem que se posicionou na frente do movimento guerrilheiro. Como aponta Zuenir Ventura, citando alguns analistas da época, os problemas desse tempo tinham muito a ver com "o problema familiar, freudiano". [...] "Aquela rapaziada de 64/68 rompeu com a estrutura repressiva do pai, da mãe, da família, que tradicionalmente absorvia a rebeldia do filho e o colocava no bom caminho" (VENTURA, 2013, p. 47). Contudo, influenciado pela experiência no campo, o protagonista apercebe-se, andando pelas ruas de São Paulo donde deve apanhar com os companheiros um voo para Porto Alegre, que a sua rebeldia era no fundo hipócrita, pois o seu estilo de vida nada diferia daquilo que ele criticava nos livros:
Ando pelas ruas e descubro que estou odiando aquela cidade, aquela gente comportada e vestida que vai para os escritórios, para as repartições, para os cinemas. [...] Aquela gente com ideias assentadas e tranquilas nas cabeças penteadas e dignas é justamente a humanidade de meus romances, a humanidade contra a qual eu combatia, eu acusava e condenava. No entanto, sou cúmplice daquela humanidade, cúmplice e escravo ao mesmo tempo: parava nos cruzamentos, ia sempre a algum lugar fazer alguma coisa que eu não queria nem precisava realmente fazer (CONY, 1967, p. 233-234).

No final do romance, Paulo parece não estar apenas determinado a abandonar a sua condição de escritor profissional que escreve por encomenda, mas também a pôr a sua obra a serviço do ideal revolucionário. Sob o impacto da morte de Vera e Macedo e, indiretamente também perante a notícia sobre o suicídio dos pais, ele troca, pelo menos temporariamente, a literatura pela luta contra a opressão, prosseguindo a missão na qual o inspiraram os seus companheiros mortos.

\section{A travessia religiosa}

Embora Pessach: a travessia aborde, primordialmente, o tema do engajamento do cidadão e artista no momento de uma crise política, como estreitamente ligada com este tema apresenta-se a questão da identidade religiosa e cultural, concretamente da identidade judaica. O livro pode, assim, também ser lido como um romance sobre o retorno às raízes hebraicas. Como aponta Renato Franco, a problemática da determinação da identidade pessoal está presente em vários outros romances da época, como por exemplo Quarup ou Confissões de Ralfo (1975), de Sérgio Sant'Anna.

Carlos Heitor Cony tinha origem semítica - o seu avô paterno descendia de judeus não-praticantes franco-marroquinos (LEVI, 2008, p. 105). Sem, antes, ter se interessado muito pelas suas raízes, o autor decidiu abordar a temática do judaísmo precisamente no romance Pesach: a travessia, tornando-o, assim, quase um divisor de águas na sua obra. Em 
uma primeira leitura, encontramos no livro vários elementos autobiográficos. Tal como o protagonista, também Cony, na época, era um escritor que produzia sob a ditadura militar; fazia quarenta anos (ele completou o seu quadragésimo aniversário em 1966); tinha passado por uma evolução até adotar uma posição claramente crítica em relação ao regime; no início afastado da sua origem hebraica, acabou por se identificar com ela; e chegou a escrever um romance com a temática judaica.

Em Pessach: a travessia, o pai do protagonista-narrador que, traumatizado pelo medo da perseguição de judeus, decide suicidar-se junto com a sua esposa, encarna o judaísmo na sua face apocalíptica, associada com o Holocausto. Contudo, a temática do judaísmo está presente sobretudo no motivo bíblico do êxodo - da fuga dos israelitas do Antigo Egito para Canaã. Este acontecimento é comemorado por Judeus durante a Pessach, uma das suas festas mais importantes. A expressão pessach (hebr. pesach, greg. pascha) significa, segundo o livro de Êxodo, o segundo dos cinco livros de Moisés, "passar por cima" (Êxodo, 12). Refere-se à décima das pragas que Deus enviou sobre o povo egípcio, e que fez com que o Faraó finalmente libertasse o povo hebreu da escravidão: o anjo da morte, enviado por Deus, tirou a vida a todos os primogénitos egípcios, passando por cima das casas dos hebreus que, instruídos pelo profeta Moisés, tinham marcado as portas com o sangue dum cordeiro sacrificado (Êxodo, 12). O Êxodo narra a história da caminhada dos hebreus que, conduzidos por Moisés, partem do Egito, onde tinham vivido por quatro séculos na escravidão, para Canaã, a terra prometida por Deus para os descendentes de Abraão. Sob a proteção divina conseguiram atravessar com o pé seco o Mar Vermelho, onde o exército egípcio na perseguição deles morreu afogado, e atravessaram o deserto até ao Monte Sinai, onde Moisés recebeu os Dez Mandamentos de Deus (Êxodo, 12-20).

No romance de Cony, o tema do êxodo aparece tanto ao nível diegético - a viagem exterior e interior de Paulo decorre em um diálogo explícito com o livro Êxodo -, como ao nível hipodiegético, através do motivo do livro homónimo, Pessach, que Paulo tenciona escrever, inspirando-se na história do Velho Testamento e na vida do seu pai. Através do uso desta técnica do romance-dentro-do-romance, o autor acentua ainda mais a relação inter-textual com a Bíblia.

Lélia Parreira Duarte, na sua comparação detalhada do romance de Cony com o livro do Êxodo (DUARTE, 1983), levanta uma série de paralelos. Mencionemos alguns deles. Em primeiro lugar, chama a atenção para a semelhança entre Paulo e Moisés ${ }^{6}$. Aponta para a simbologia do número quarenta na Bíblia, associado aos significados de prova ou castigo (DUARTE, 1983, p. 33). Quando completa os quarenta anos, Moisés visita os seus irmãos hebreus, apercebendo-se da situação miserável em que vivem. Ao matar um egípcio por ter batido em um hebreu, entra em conflito com o Faraó e tem que fugir do Egito. Passados mais quarenta anos, recebe a mensagem de Deus, através do seu mensageiro, que o incita a voltar ao Egito e a libertar o seu povo da escravidão. Paulo Simões, por sua vez, no dia em que completava quarenta anos, é convidado por Sílvio e Vera para ajudar a lutar contra a ditadura. Além disso, tanto Moisés quanto Paulo representam, na primeira parte da sua vida, pessoas alienadas das suas raízes, suspeitas aos olhos dos outros. Moisés, após ter sido resgatado da água pela filha do Faraó, foi criado em opulência no palácio faraónico, enquanto o povo hebreu sofria na escravidão; Paulo leva uma existência acomodada de um escritor burguês, desinteressado da opressão social e política ao seu redor. $\mathrm{E}$ ambos enfrentam dúvidas quanto às suas capacidades de cumprir a tarefa que lhes é dada (DUARTE, 1983, p. 36-39). Podemos acrescentar que na viagem com os seus próximos passam por situações parecidas: igualmente aos hebreus que atravessaram o Mar Vermelho a pé enxuto, porque "o mar tornou-se em seco e as águas foram partidas" (Êxodo, 14, 21), também Paulo consegue cruzar um

6 Malcolm Silverman aponta para o fato de que o sobrenome de Paulo, Simões, é, na verdade, um anagrama do nome do profeta do Velho Testamento (Cf. SILVERMAN, 2000, p. 292). 
riacho na fronteira, durante uma seca, "quase a pé" (CONY, 1967, p. 288).

No entanto, Duarte também observa vários paralelos entre Moisés e Macedo que, com a sua figura forte e capacidades de líder, faz lembrar o profeta do Velho Testamento e o salvador dos hebreus. Esta semelhança é, aliás, no livro explicitamente mencionada: "Para minha surpresa, Macedo me lembra a passagem do Mar Vermelho. Deixo o falar. [...] Quando acaba, digo que o vira tomar banho e que ele, imenso do corpo, me parecera um Moisés esculpido em carne" (CONY, 1967, p. 288). Macedo está predestinado a liderar a luta armada: além da compleição física, força interior e a fama heroica que o circunda, possui motivações psicológicas - a sua família e ele próprio foram duramente perseguidos pelo regime ditatorial. Mutilado e impotente devido à tortura sofrida na prisão, lutando contra o vício do álcool, trata-se de uma personagem complexa, de contradições, que vão da agressividade à humanidade profunda. Engaja-se na guerrilha sem acreditar no seu sucesso, pois toma em consideração a força militar do regime e o seu apoio pelos Estados Unidos. Macedo torna-se o trágico Moisés da guerrilha brasileira, o profeta da sua inevitável derrota. Por outro lado, encarna a fé na necessidade de lutar até ao fim, de não desistir, mesmo que a luta pareça perdida, pois não é apenas da luta coletiva que se trata, mas também da luta pessoal:

- Nenhum homem mutilado como eu pode ser um Moisés. Que cada um seja o seu próprio Moisés, atravesse o rio e, mais tarde, quando puder, regresse para lutar outra vez. Afinal, Moisés também fugiu. O importante é voltar, depois (CONY, 1967, p. 288).

\section{A travessia brasileira}

As três transformações do protagonista de Pessach: a travessia, que ocorrem simultaneamente e, como vimos, no âmbito dos cronotopos da natureza e da estrada, são inseparáveis do momento histórico em que se operam, ou seja, das transformações pelas quais passava a sociedade brasileira à época. Esta foi a razão pela qual inserimos esse romance dentro do quinto tipo do romance de formação em que, segundo Bakhtin, a evolução do homem "reflete em si mesmo a formação histórica do mundo". Nesse tipo de romance, "o homem já não se situa no interior de uma época, mas na fronteira de duas épocas, no ponto de passagem de uma época para outra. Essa passagem efetua-se nele e através dele. Ele é obrigado a tornar-se um novo tipo de homem, ainda inédito" (BAKHTIN, 1997, p. 241).

O romance de Carlos Heitor Cony reflete, através das vacilações do protagonista e das suas conversas com as pessoas ao redor, várias posições ideológicas existentes na sociedade brasileira depois do golpe, em relação à situação atual no País. Encontramos nele, por exemplo, uma alusão à atitude conservadora e simpatizante com o regime militar, adotada por alguns setores da Igreja Católica, que são representados pela freira com a qual Paulo entra em diálogo, quando esta lhe pede uma contribuição para as missões internacionais:

- Continuo insistindo na recusa, Irmã. Não sou de dar conselhos mas acho bobagem a senhora preocupar-se com os pagãos da Manchúria. Deveria preocupar-se é com os cristãos daqui. Sabe que no Nordeste há milhões de pessoas batizadas e comungadas que morrem de fome? - Mas o Brasil vai, pouco a pouco, resolvendo este problema. Agora que os comunistas foram afastados, o governo vai cuidar dessa gente. $\mathrm{O}$ nosso marechal é homem muito religioso! Vai à missa todos os domingos e comunga pela Páscoa da Ressurreição.

- Pois o vosso piedoso marechal está é metendo toda essa gente na cadeia, Irmã. Não quero ser indelicado, mas arranje outra forma de me arrancar o dinheiro (CONY, 1967, p. 49).

A atitude descomprometida de uma grande parte de intelectuais da classe média, na questão do engajamento político, é encarnada, tanto na inicial descrença de Paulo, como também na postura um tanto alibista do editor dos seus livros: 
Minha trincheira é aqui, nesta editora, publicando livros que, de uma forma ou outra, ajudam a criar uma consciência de nossos problemas e uma antevisão de nossas soluções. Fora destes termos, ninguém pode contar comigo para nada (CONY, 1967, p. 93).

O romance, porém, apresenta sobretudo o debate da esquerda brasileira acerca do projeto revolucionário, que muitos encaravam como a única via de como acabar com as injustiças no seu país e no mundo em geral. O momento era considerado crucial para a tomada de ação, como demonstra a convicção de Sílvio: "O País, a Humanidade, estão na cruzilhada. Só há duas atitudes: ou ficamos sentados, à beira da estrada, sem tomar nenhum dos caminhos, ou optamos por um deles" (CONY, 1967, p. 24). Sílvio esboça a situação alarmante no país com as palavras seguintes:

Para resumir, apenas enumerando os problemas mais agudos, aí vai: ditadura, supressão das liberdades públicas e individuais, exploração estrangeira, fome nas classes baixas, empobrecimento brutal das classes médias, degradação da pessoa humana, violências, policiais, torturas e assassínios. Você não pode aceitar a vida - a vida da nossa época - sob condições tão infames e infamantes, tão inumanas. Ficar sentado equivale a uma cumplicidade criminosa (CONY, 1967, p. 24-25).

O romance apresenta também interessantes visões - embora não comprovadas pela evolução histórica -, a respeito da futura evolução da situação internacional no ambiente da Guerra Fria, e da posição do Brasil nesse contexto:

Daqui a três anos a China Comunista terá um poderio atômico tão grande que Moscou e Washington serão, talvez, obrigados a se unirem. E dessa união nascerá uma política imperialista que colocará o Brasil eternamente na fossa. Temos, no máximo, três anos para resolvermos nossos problemas mais imediatos. Quando a situação internacional engrossar, seremos um povo e um país com reservas e disponibilidades bastantes para escolhermos o nosso próprio caminho. (CONY, 1967, p. 25).

É sobretudo por meio da personagem de Sílvio que o autor exprime a convicção, própria de uma parte da esquerda brasileira, sobre a viabilidade e a madureza do plano da tomada de poder armada no País, no que se refere ao seu abastecimento de recursos materiais e humanos:

Estruturamos um programa revolucionário que, a princípio, parecia romântico, impraticável. Mas os acontecimentos precipitaram-se, surgiram acasos que nem em sonhos podíamos imaginar, recebemos ajudas e cooperações inesperadas, principalmente no que diz respeito a recursos financeiros. Hoje, temos condições que podemos considerar mais que objetivas. Resta apenas ultimar os preparativos e convocar alguns elementos necessários. Já temos teóricos, economistas, intendentes, temos bastante dinheiro para a luta. Principalmente, bastante tropa, gente que não acaba mais e que aumenta a cada dia (CONY, 1967, p. 27-28).

O mesmo otimismo é expresso por um líder guerrilheiro no Rio Grande do Sul, que explica o plano de, primeiro, dominar uma parte estratégica da região e de forçar os militares a entrarem em diálogo com a oposição e, segundo, obrigar o governo a demitir-se, perante o perigo de uma guerra civil. As suas palavras repercutem a utopia revolucionária da época, baseada na convicção de que a guerrilha tinha o apoio da maioria da sociedade brasileira:

Além do mais, contamos com o apoio da própria população: a maioria dos habitantes, como a maioria de todo o povo, está do nosso lado. [...] Se conseguirmos manter esse território por cinco ou seis dias, a ditadura cai. Pelo resto do Brasil tudo está minado, quartéis, cidades, usinas, fábricas, a própria classe média, os próprios capitalistas brasileiros estão loucos para verem esse governo no chão. Basta criarmos esse fato novo e os políticos, os empresários nacionais, os militares nacionalistas, a classe média que está se proletarizando, estudantes, lavradores, 
operários, enfim, a Nação inteira estará de nosso lado. Ainda que não queira lutar, ela apoiará a nossa luta (CONY, 1967, p. 257).

Do mesmo modo, mostra-se ilusória a fé no apoio político do movimento libertador por parte dos países estrangeiros:

Veja, a ditadura exilou os brasileiros de maior prestígio internacional. Essa gente toda está trabalhando, nos Estados Unidos, na ONU, em Genebra, em Paris, no Vaticano, em Moscou. Estamos criando uma condição concreta de apoio internacional ao nosso movimento (CONY, 1967, p. 259).

O líder guerrilheiro Macedo, pelo contrário, mostra uma visão mais realista, marcada por dúvidas quanto à eficiência da luta armada, apresentando como motivos a sua baixa efetividade e divergências entre as diversas organizações, que na sua maioria surgiram como dissidentes do Partido Comunista que não apoiou a luta armada. No que diz respeito à estratégia da luta, Macedo mostra incertezas: por uma lado, está de acordo com a tomada de poder armada nos lugares estratégicos no interior, por outro lado acredita na negociação política com o governo, com o objetivo de evitar maior derramamento de sangue.

Renato Franco, a este respeito, chama a atenção para uma diferença importante entre Pessach: a travessia e Quarup de Antônio Callado: enquanto este relaciona-se mais com os ideais políticos dos anos 1960, que visavam uma revolução popular (o enredo do livro termina logo depois do golpe de 1964), o livro de Cony exprime a atmosfera marcada pela constituição e ação de vários grupos guerrilheiros, estando assim "mais atado às circunstâncias políticas que geraram a luta armada do final dos anos $1960 \mathrm{e}$ início da década seguinte" (FRANCO, 1998, p. 60). $O$ romance de Cony capta assim a luta armada no Brasil na fase de transição, quando ainda se nutria pela utopia revolucionária, mas já enfrentava uma perda de ilusões, que veio com 1964, e em breve ia viver uma perda de inocência, chegada em 1968 (VENTURA, 2013, p. 46).
A travessia de Paulo Simões insere-se neste contexto. Ela se realiza no sentido da abertura da sua personalidade para o mundo, através da consciencialização do "eu" como parte de uma comunidade, pela percepção do vínculo do destino do indivíduo com o destino do coletivo. Não é, porém, uma travessia maniqueísta do apoliticismo ao engajamento, pois em todo o seu decurso é acompanhada por questionamentos, contradições e consciência da sua possível derrota. Por esta razão, podemos vê-la como uma viagem cujo fim não reside no fim, mas no próprio ato de viajar: "o importante não era a conquista em si, mas a travessia, a busca - os pães não fermentados - e repudiar o cativeiro, a passividade escrava, o grilhão" (CONY 1967, p. 80).

\section{Referências}

BAKHTIN, Mikhail Mikhailovitch. Estética da criação verbal. São Paulo: Martins Fontes, 1997.

BAKHTIN, Mikhail Mikhailovitch. Questões de literatura e estética. São Paulo: Editora UNESP, 1993.

CONY, Carlos Heitor. A revolução dos caranguejos. São Paulo: Companhia das Letras, 2004.

CONY, Carlos Heitor. O ato e o fato. Rio de Janeiro: Civilização Brasileira, 1964.

DUARTE, Lélia Parreira. Pessach: a travessia - narrativa especular. Letras de Hoje, Porto Alegre, v. 16, n. 1, p. 31-48, 1983.

ÊXODO. In: Bíblia Sagrada. Trad. João Ferreira de Almeida. Lisboa: Sociedades Bíblicas Unidas, 1993, p. 61-109.

FRANCO, Renato. Itinerário político do romance pós-64: A festa. São Paulo: Fundação Editora da UNESP, 1998.

GASPARI, Elio. A ditadura envergonhada, v. 1. Coleção As ilusões armadas. São Paulo: Companhia das Letras, 2002.

LEVI, Joseph Abraham. Duas imagens do judaísmo brasileiro: O caso de Pessach: A Travessia de Carlos Heitor Cony e Hitler manda lembranças de Roberto Drummond. Cadernos de Estudos Sefarditas, Lisboa, n. 8, 103-128, 2008. Disponível em: http://www.catedra-alberto-benveniste.org/_fich/15/ Joseph_Abraham_Levi.pdf. Acesso em: 15 fev. 2019. https:// doi.org/10.5007/2175-7917.2018v23n2p182

NETTO, José Paulo. Pequena história da ditadura brasileira (1964-1985). São Paulo: Cortez, 2014.

REIMÃO, Sandra. Repressão e resistência: censura e livros na ditadura militar. São Paulo: Editora da Universidade de São Paulo, Fapesp, 2011. https://doi.org/10.5212/uniletras. V.35i1.0012 
ROSA, João Guimarães. Grande sertão: veredas. Rio de Janeiro: Nova Aguilar, 1994.

SILVERMAN, Malcolm. Protesto e o novo romance brasileiro. Rio de Janeiro: Civilização Brasileira, 2000.

VENTURA, Zuenir. 1968: o ano que não terminou. Rio de Janeiro: Objetiva, 2013.

Enviado em: 12/3/2019.

Aprovado em: 9/4/2019.

\section{Zuzana Burianová}

Universidade Palacký em Olomouc (UP) - República Checa

Orcid: http://orcid.org/oooo-0002-3530-8473

E-mail: zuzana.burianova@upol.cz

Endereço de correspondência:

Katedra romanistiky

Filozofická fakulta Univerzity Palackého

Krízkovského 10

77180 Olomouc

Czech Republic 